\title{
The 'Regulatory State' in Higher Education: Assuring Quality through New Modalities of Control in Brazil ${ }^{1}$
}

\author{
FLAVIA MARIA DE MATTOS DONADELLI
}

Victoria University of Wellington, New Zealand

The Brazilian Higher Education (HE) sector following a global trend of rapid transformation has undergone marked changes over the past two decades. These changes have involved the design of quality assurance tools as instruments for regulatory governance. In presenting an overview of the recent history and characteristics of quality assurance in the Brazilian HE sector, this paper contextualises the Brazilian experience according to broader conceptual frameworks and discusses how and why regulatory governance in this sector has so radically changed.

\footnotetext{
${ }^{1}$ A latter version of this paper was accepted for publication at the Bulletin of Latin American Research.
} 
Key-words: Brazil, higher education, educational policies, quality assurance, regulatory governance, regulatory state

There has been an emerging scholarly debate on the rise of the 'regulatory' or 'evaluative' state in HE around the world (King, 2007; Majone, 1997). Departing from a long tradition of self-evaluation and academic independence, more than half of the countries in the world are now said to be regulating HE through Quality assurance (QA) tools and agencies (Jarvis, 2014; Jordana; 2018). Despite this 'explosion of oversight' and although some studies have pointed to the variation in $\mathrm{HE}$ quality assurance regulation, little is still known on the particularities of HE governance systems in different contexts (Hood and Scott, 2004). Differences have been identified not only in the type of regulatory instruments used to assess and measure quality, but also in the way that similar instruments work and perform in different countries (Billing, 2004; Brennan and Shah, 2000; Hood and Scott, 2004; Jordana, 2018).

This article aims to contribute to this broader debate by focusing on the use of $\mathrm{HE}$ quality assurance tools and instruments of HE regulatory governance in the Brazilian case. It traces the history of HE regulation changes in Brazil since 1999, shows commonalities with broader regulatory governance trends and discusses how and why it has assumed its current features. In particular, the article investigates whether the Brazilian HE sector is representative of an international trend towards the 'Regulatory' or 'Evaluative State'. That is an adoption of less interventionist or more 'remote' regulatory strategies, based on competition and self-governance and a posteriori (in the aftermath) methods of accountability and evaluation (Majone, 1997; Neave, 1998). Or if the case epitomises a trend towards the 'Post-regulatory' State, where civil society acquires an even more central role in regulatory control, signals a collapse of the traditional distinction of public and private regulation, in a widely decentred and self-governing governance system (Black, 2001; Scott, 2004).

Several and drastic changes affected the Brazilian HE sector in the past three decades. In 1999, private for-profit institutions were allowed to operate in the country which led to a proliferation of private education providers to the point where 87.9 percent of all $\mathrm{HE}$ institutions in Brazil are private (INEP, 2018), and 45.2 percent of the sector are composed of for-profit institutions. In addition to the new composition, the sector as a whole has expanded 
from approximately two million and three hundrednew enrolments in under-graduate courses in 1999 , to more than eight million in 2018 , a four-fold increase in less than two decades (INEP, 1999; INEP, 2018). Finally, the implementation of socio-educational policies such as the Programa Universidade para Todos (ProUni, University For All Programme) in 2004 and the expansion of Fundo de Financiamento ao Estudante do Ensino Superior (FIES, Higher Education Students Finance Fund) in 2010 crucially shaped the recent history of the sector by making for-profit institutions accessible to lower income students. The former programme instituted tax exemptions to educational institutions that offered scholarships to lower income students, whilst the latter facilitated the provision of student loans by the financial sector (Oliveira, 2009).

By tracing the history of the sector's changes in Brazil from 1999, this article shows that, differently to the general expectations of the 'Regulatory State' and 'Postregulatory State' theory, the country has migrated from a model of academic self-governance, with a considerably light-touch regulatory approach, towards a mix of hierarchical controls and market-oriented tools. Interestingly, neither the 'Regulatory State' arm's length regulatory strategies nor the 'post-regulatory' state expected mutuality, peer-evaluation and networking have received as much emphasis as traditional state oversight in the Brazilian case. It concludes that despite participating in a global trend of expansion in regulatory governance mechanisms and new quality assurance tools in HE (Jordana, 2018), the direction of $\mathrm{HE}$ regulatory governance reforms in Brazil are specific to the Brazilian context, displaying elements of a very hierarchical state. These findings point to a moderate degree of international diffusion of the 'regulatory state' model of HE in Brazil, as it remains strongly mediated by 'path-dependency', the Brazilian 'national style' of regulation and the history of local institutions (Pierson, 2000; Vogel, 1997).

The paper is organised as follows. Section two theoretically contextualises the case according to broader debates on HE regulatory governance, it introduces the main modalities of control and the methods through which the case is analysed. Section three provides a background of the recent history of Brazilian HE regulatory governance, a description of the main actors of the sector and of the central quality assurance institutions and regulatory instruments currently in place. Section four discusses and presents the main results of the analysis. Section seven concludes. 


\section{The Rise of the 'Regulatory State' in HE}

Most of the big structural changes in the public sector can be attributed to changes in forms of control. Hood and Scott (2004) distinguish four basic types of control: mutuality, competition, oversight and contrived randomness. Mutuality is distinguished by egalitarian or horizontal types of control that arise from the influence of a peer group. Peer review of academic papers or the self-evaluation of institutions are examples of this type of control. This puts academic faculty at the centre of university governance. Oversight is hierarchical, in that it implies external and authoritative control. Any sort of requirements from external authorities would classify as oversight. Typical examples in the area of HE would involve government requirements in terms of curriculum, or licensing for HE institutions to operate. Competition is a rivalry-based type of control. This implies behavioural change when universities act in a way to perform better through publication of rankings, increase in students numbers and the implementation of productivity-based promotions and rewards. Finally, contrived randomness are controls that rely on chance or quasi-lottery systems. They might be designed as surprise inspections or result from a lack of consistency in the implementation of other mechanisms of control. An example of unintended contrived randomness might be the degree of subjectivity in in loco evaluations of HE institutions by academics or government representatives, when clear and objective criteria have not been designed. Another example could be variations in the degree of difficulty of national examinations of students' learning and the lack of validity or reliability in using the outcomes as quality indicators.

The move from the 'positive' towards the 'regulatory state' implies that governments have moved away from a direct provision of services and controls towards a stewardship role of society and the economy, through 'remote' regulatory tools. Studies have argued that the regulatory state has now materialised in the HE sector, but that few analyses exist on the particularities and operation of these new governance mechanisms around the world (King, 2007; Jordana, 2018). A common feature of the regulatory state, as described in the literature, encompasses a shift from 'command-and-control' regulation towards a reliance on market and self-regulatory mechanisms of control, based on the responsiveness by those regulated and/or risk-based intervention (Ayres and Braithwaite 1992; Gunningham and Grabosky 1998). This shift to 'indirect' or 'proxy' government warrants the dispersion of the 
traditional state bureaucratic-hierarchic regulatory authority to other social actors, resulting in greater pluralism, diffusion of power, and extensive delegation of tasks to non-majoritarian institutions (Majone, 1997). Evidence of such a change would comprise the emergence of market-based or community-based governance mechanisms with a less direct role for governments in the control of social sectors such as HE. This trend has been pushed even further to a point where 'post-regulatory' or the 'decentred' state, devolves regulatory power from government to society blurring the distinction between government and private forms of regulation (Scott, 2004; Black, 2001).

However, international 'regulatory games' often present 'national rules' which are mediated by national institutions, interest groups and regulatory culture (Vogel, 1986; 1997; Vogel and Keleman, 2010; Radaelli, 2004, Jordana and Sancho, 2004). Comparative studies show that regulatory reform in different countries, often tend to have their own national patterns or styles. Assessing finance and telecommunication regulatory reforms in Japan and UK, for example, Vogel (1997) found that country specific production profiles; different levels of autonomy for civil servants (from politicians and market influences); and, the ideas through which decision makers 'filter' market forces result in different trajectories of liberalisation and modes of 'reregulation'. Similarly, Jordana and Sancho (2004) stress the importance of processes and influences that lie behind the formal similarities of the regulatory state. The focus on 'institutional constellations', defined as '[...] the entire sets of formal institutions and interconnected rules that shape public decision-making in a given regulatory arena, including shared interpretative structures' (Jordana and Sancho 2004: 298) captures this notion and provides a useful analytical tool for addressing contextual variation.

Studies that have assessed the particularities of the Brazilian 'regulatory State', or the impact of national 'institutional constellations' on regulatory reforms in the country, seem to point to similar findings. Cunha and Rodrigo (2012) observe the challenges of implementing regulatory reforms in Brazil, pointing out the limited levels of regulatory agency autonomy, blurred competencies between institutions, plus a lack of institutional leadership and commitment towards the 'regulatory state'. The country is portrayed by the authors as retaining the characteristics of an interventionist or positive state. Peci and Sobral (2011:213) point to the fragmentation of the regulatory system in Brazil and confusion as to the division of responsibilities between regulatory agencies and their ministries.

Writing in broader terms, some characterisations of the 'regulatory state of the south' (Dubash and Morgan, 2012) or of the 'Latin American Regulatory State' (Jordana, 2011) resonate with the Brazilian analysis rendered by the abovementioned authors. There seems to 
be a consensus that the expansion of de jure political delegation to regulatory agencies in Latin American countries, did not mean a de facto political delegation. Indeed the strong presidential traditions of the countries of the region, manifests itself through the continuation of supervision and guidance of regulatory agencies by the executive (Jordana, 2011:165). Debates on the interaction between the 'regulatory' and 'developmental' states of the South (such as in Brazil), point to an increase in the politicisation of regulatory agencies (Prado, 2008). As opposed to the depictions of the 'regulatory state', these contextual analyses suggest a more hierarchical orientation of regulatory tools in Brazil.

Based on these debates, and mapping the recent governance changes, institutional actors, regulatory strategies and the overall regulatory style of HE regulation in Brazil, this study shows a tendency towards hierarchical/centralised control as opposed to the expectations of self-regulation or market-based instruments theorised by traditional descriptions of the 'regulatory state'. By referring to secondary sources, agencies websites, governmental reports and statistics, the paper assesses the 'definition of quality standards at the level of policy formulation' over the past twenty years in Brazil (Jordana, 2018). Studying the characteristics and changes in 'the policy dimension of quality assurance practices' in Brazil, the paper describes the system of HE regulatory governance in Brazil, identifies tools of regulatory control, and analyses changes in patterns or 'forms of control' according to Hood and Scott's typology of control (Hood and Scott, 2004).

\section{The Brazilian Case}

\section{History and Background}

The Brazilian HE system was established at the beginning of the nineteenth century to supply the nobility with basic professional services (such as medical, legal and engineering services) and was, at first, directly financed by the Crown. It was not until the end of the nineteenth century that autonomous HE institutions started to emerge in the country.

The first HE policy in Brazil is established in 1879, allowing autonomous HE institutions to operate. This was subject to the 'necessary inspections in order to guarantee conditions of hygiene and morality' (Câmara dos Deputados, , 1879, art. 1). Basic instruments of in loco verifications were established and subsequent legislation was created for the authorisation of 
these institutions (new regulations were published in 1938 and 1962). By the end of the 80s, Brazil had around $871 \mathrm{HE}$ institutions and more than one million and five hundred $\mathrm{HE}$ students (Unesco, 2020). Although the institutions were autonomous and could generate profit to be reinvested in the institution, they were still legally classified as philanthropic or social assistance institutions, and were not subject to regulation or profit enhancing logic of commercial entities.

Due to a local financial crisis and 'conditionalities' associated with loans received from the International Monetary Fund (IMF) and World Bank (WB) in 1992 and 1998, the Brazilian government started to prioritise 'small state' policies, which lead to dramatic cuts to public funding for the HE sector. In 1994, President Itamar Franco recognised the commercial basis of $\mathrm{HE}$ in Brazil, and therefore determined it should be subjected to the national Consumer Code and to the regulation of the Fundação de Proteção ao Consumidor (PROCON, Consumer Protection Foundation). This measure was complemented by President Fernando Henrique Cardoso in 1999, who published regulations that opened the sector to commercial/for-profit institutions. This allowed institutions, previously registered as private philanthropic, communitarian or confessional entities, to become for-profit organisations (Nunes, et al. 2014).

HE institutions in Brazil could then be registered as public or private - for-profit or non-profit - entities. Public institutions did not charge any tuition fees and could be funded by the federal, state or municipal level of government. Private institutions could be for profit or non-profit (a category divided in communitarian, when they involve representatives of their communities; confessional, having an ideological or religious orientation, and philanthropic, meaning they should complement state activity through the provision of public services to the society). (Ministério das Relações Exteriores, 2018)).

Since the establishment of these regulatory changes, the number of private forprofit institutions has substantially increased. From zero in 1999 to 1,088 in 2017, surpassing the number of private non-profit institutions in 2011. Similarly the number of students has risen from private institutions having 6,241,307 new enrolments in under-graduate courses in 2017, as opposed to 2,045,356 in public institutions (INEP 2018). The number of new enrolments in private institutions surpassed both public and private non-profit institutions by 2012. In 2014 students in private institutions constituted 42 percent of the total number of students enrolled in HE in Brazil. (Verhine and Dantas, 2015) Data demonstrates, that this 
'privatisation trend' of the sector has increased over time. While the absolute number of enrolments in private institutions has increased by $1,100,995$ additional enrolments between 2012 and 2017, the number of enrolments in public institutions only saw a slight increase of 147,980 additional enrolments. (INEP, 2018).

Interestingly, this expansion in the private for-profit sector was not matched by students' demand, resulting, at first, in numerous unfilled places. While the centre-right government of Fernando Henrique Cardoso allowed for the expansion of the HE private sector through more permissive regulations in 1999, policies implemented by the centre-left governments of Lula da Silva (2003 - 2011) and Dilma Rousseff (2011 - 2016), both from the Partido dos Trabalhadores (PT, Workers' Party), contributed to filling in previously vacant for-profit university places. Two policies were critical in this regard. Firstly the FIES, launched in 2001 by Cardoso and expanded in 2010 by Lula, and secondly the ProUni, established in 2004 by Lula. The former favoured private institutions by facilitating student loans, the latter granted private institutions with tax exemptions for providing scholarships to lower income students. ProUni established that, in order to be part of the programme, forprofit institutions should provide at least 1 full scholarship to every 10.7 paying students or a total of 22 full scholarships plus partial scholarships adding up to at least 8.5 percent of their gross revenue (Almeida de Carvalho, 2006). The selection criteria for a scholarship stipulated that a student must have studied in public schools during their entire high school period, or that they should have received full scholarships if attending private schools. Additionally, scholarship students had to have a family income below three minimal wages (corresponding to USD735 per month according to the January 2020 exchange rate). A percentage of the scholarships, corresponding to their percentage in the demographic census were reserved for applicants self-declaring as disabled, indigenous, black or mixed race. (Davies, 2016)

By making private $\mathrm{HE}$ accessible to lower income and minority groups the government indirectly transferred public resources to private educational institutions through the provision of student scholarships, or low-interest student loans. The consequence was a massification of HE, that while supporting lower income and minority groups, also favoured big educational corporations to fill in vacant places and contributed to the reduction of default rates. Although public universities have expanded during the Workers' Party mandate with the launch of the Programa deReestruturação e Expansão das Universidades Federais (REUNI, Programme for Restructuration and Expansion of Federal Universities), and 
affirmative action being taken for minority groups to access these institutions, the main impact of the HE policies during Lula and Dilma's governments was an expansion of private for-profit education and a new system of quality assurance tools.

As the government instituted more centralised type of quality assessment, this reduced institutional autonomy and created in its stead a more punitive approach. The expansion of private for-profit institutions in the sector also led to the need for regulations to be both punitive (to control extreme levels of rent-seeking behaviour) and less resource intensive given the limitations of governmental institutional apparatus and capacity.

\section{Actors}

At least four actors can be identified in the governance of HE quality assurance in Brazil. The most visible is the government or the Ministry of Education, which is legally mandated to regulate and guarantee the quality of HE provision. The operational agency of the Ministry of Education is the Instituto Nacional de Estudos e Pesquisas Educacionais Anísio Teixeira (INEP, Anísio Teixeira National Institute of Educational Studies and Research), who oversees data collection and analysis, assisting the Ministry in the elaboration of educational policies.

Another important governmental institution is Comissão Nacional de Avaliação da Educação Superior (CONAES, National Commission of HE Evaluation). This is an autonomous council that regulates directives and mechanisms, as well as providing analysis and tools for quality improvement of HE institutions. CONAES is composed of: thirteen unpaid representatives, including one representative of HE teaching staff; one representative for HE students; one HE administrative staff; one representative from a public institution focused on post-graduation evaluations and promotion (Coordenação de Aperfeiçoamento de Pessoal de Nível Superior, CAPES, Coordination of the Improvement of HE Personnel); three members of the Ministry of Education; and, five experts in HE evaluation and management appointed by the Ministry of Education. Despite its formal mandate CONAES role was assumed by the Ministry of Education, and little decision power currently remains with CONAES (Nunes, Fernandes and Albrecht 2014). In 2006, the Comissão Técnica de Acompanhamento da Avaliação (CTAA, Technical Commission for Evaluation) was created within INEP to issue final decisions on contested evaluation reports and to appoint in loco evaluators. CTAA increased INEP's decision-making power and reduced CONAES to a 
discussion and networking forum (Francisco and Marback Neto 2016). Finally, within the Ministry of Education, the Secretaria de Regulação e Supervisão da Educação Superior (SERES, HE Regulation and Supervision Secretariat), is in charge of 'top-down regulations', being responsible for the establishment of national curricular standards and quality directives for courses and institutions. Overall, despite the initial goal of promoting deliberative and horizontal decisions with the creation of CONAES, the analysis of its de facto mandate demonstrates that quality assurance regulations remain highly hierarchical and centralised by the Ministry of Education.

The second important group of actors in the HE sector is the large group of forprofit educational conglomerates that have emerged since 1999. This is a remarkably large and influential group. The largest eight private educational groups in Brazil represent 2.1 million students. This figure corresponds to 27.8 percent of the total of Brazilian students in $\mathrm{HE}$, and exceeds the total number of students in the entire public education system $(25.1$ percent) (Toledo, 2016). The economic and political power of these private educational conglomerates has a direct influence on regulatory decision making within the Brazilian HE system.

One of the most powerful representatives of this group are Kroton, who made a net profit of 2.2 Billion reais in 2017 (approximately 0.6 Billion dollars), who figure amongst the fifteen most profitable companies in the country (Salomão, 2018). In 2016, Kroton had approximately 876 thousand students, and directly participated in the regulatory processes of the country through a constant dialogue with the government. A brief overview of the decisions of the Conselho Nacional de Educação (CNE, National Education Council) in terms of evaluation criteria and procedures from 1996 to 2017, showed that the government was constantly challenged by Kroton, being required, for example, to judicially justify its mandate to regulate and intervene in the provision of HE (Ministry of Education, 2018). One of the several examples of the nature of this interaction was the request by private for-profit conglomerates for the government to revise its requirements for the application of faculties or university centres to become universities. The request was attended by the government in 2017, with the elimination of specific requirements of research productivity. (CNE, 2017)

A third group of relevant but more silent actors are the research-intensive public and private universities. Pre-dating the 'privatisation trend', these institutions tend to have a much clearer focus on research excellence. Although formally regulated by the current 
system, their participation in the process and the effect of the regulatory system on their performance and behaviour is minimal, performing above the minimum requirements, and relying on their reputation, undergraduate courses from research-oriented institutions have been largely unaffected by the current evaluation system.

Through its mandate to determine course curricula and, consequently, through its capacity to decide what is evaluated by the Student Performance Evaluation - ENADE the professional corporations are also important participants in the regulatory process. 40 professional corporations are involved in the design of HE courses, leading to a 'regulated profession'. Which means that these corporations have a direct effect on the conception of HE quality in Brazil as they can determine their taught subjects, and what is evaluated in terms of student's performance.

In summary, four actors interact in this regulatory realm. The government has reformed the system of HE quality assurance in order to keep minimal standards of $\mathrm{HE}$ quality in face of a dramatic increase in the number of private institutions. The newly instituted for-profit educational providers have often assumed the role of lobbyists for lower, clearer and easier-to-comply quality standards. The traditional research centres have not been directly affected by the emerging regulatory apparatus retaining most of their autonomy. Professional corporations have become one of the key groups to decide on what is to be evaluated in terms of HE quality (especially at undergraduate level). The next section will clarify the processes and methods of assuring quality of HE in Brazil and provide a clearer picture of how these actors interact.

\section{Quality Assurance Institutions and Regulatory Strategies}

After profit-seeking institutions entered the Brazilian HE sector in 1999, quality assurance concerns gained centrality in government debates. The National Education Plan passed by the Congress in 2001, instituted an HE national evaluation system and five years later, the Sistema Nacional de Avaliação da Educação Superior (SINAES, National System of HE Evaluation) was legislated.

In terms of behaviour modification strategies, the quality assurance system adopts two discernible paths. These rely on numerical indicators of quality. The first is pursued by SERES and consists in the initial authorisation and periodic licensing of institutions 
according to an institutional quality indicator, course quality indicator, and a student's performance in a national exam. Depending on the institutions' performance against these three criteria, they may even be prevented from operating. The second is the online publication of course quality indicators, and of student examination results on the Ministry of Education's website - a reputational and competition-based type of regulatory tool.

The licensing process is premised on an initial authorisation and periodic license renewals, which vary in duration according to the type of institution and how it is categorised as faculty, university centre or university. If institutions are licensed for the first time, or if they perform below a certain level in the course indicators, they have to go through a process which involves an in loco visit by a group of 2 selected evaluators who spend 2 days in the institution and produce the indicador de qualidade institucional (IQI, Indicator of Institutional Quality). The IQI is based on three main criteria: a) Institutional Organisation, assessing elements such as the existence of a mission, the existence of a plan of institutional development, the presence of representation mechanisms for students and staff, the existence of a system of self-evaluation, among others; b) Social Body (corpo social), involving elements such as teaching staff qualifications, career plan, quality of administrative staff and systems and policies of stimulus to the scientific production (note that scientific production by itself is not considered); and, c) Physical Infra-structure, related to elements such as the conditions and availability of a library, auditoriums, toilets and common areas (CNE, 2007). Each of the sub-criteria of these three major indicators are divided into a scale from one to five, according to which external evaluators classify the institution during their visits. The achievement of anything above three is considered of 'satisfactory quality'. Therefore, institutions that achieve three, four and five are treated equally, and receive their license to operate, meaning that they can enrol new students and are not subject to further scrutiny.

Although the Ministry of Education originally required in loco visits for every license to be conceded or renewed, this procedure was revised in 2008 due to its high cost and capacity demands. Subsequently, two course indicators were created in order to select only the worst performer institutions for in loco evaluations: the Conceito Preliminar de Cursos (CPC,Preliminar Course Index), and the Índice Geral de Cursos (IGC, General Couse Index). Institutions with an average rating of three or more on this five-point scale, would then be exempt from in loco evaluations for license renewal. The CPC refers to the evaluation of individual under-graduate course. It is composed of: an indicator for student performance improvement while at university (or the difference in the performance before and after taking 
the degree - measured through a national examination the Exame Nacional de Desempenho dos Estudantes (ENADE, National Examination of Student Performance); student opinion about infra-structure and staff quality; and, the percentage of staff with Masters, $\mathrm{PhD}$ and hired as full-time employees. As approximately 70 percent of CPC's results are based either on student opinion or performance, this has raised concerns about its validity as a measure of educational quality (see Nunes, Fernandes, Abrecht 2014). The IGC on the other hand, refers to the institution. It is a weighted average of the CPC results for each course plus the average student performance in the national evaluation for three years, which is largely based on student evaluations and performance. Evaluations by CAPES, the agency responsible for post-graduate educational policy are also included in the IGC in case of institutions that offer post-graduate courses. The impact of CAPES evaluations tends however, to be low in the case of private institutions, given that 83 percent of institutions that offer post-graduate courses are public institutions. The data for the IGC is, therefore, mostly collected by the HE institutions themselves, based on a student's performance and opinions, and is used to determine whether in loco evaluations for the renewal of licenses are necessary.

ENADE (the national student performance examination used to compose CPC and IGC) is formulated by the Ministry of Education according to the National Curriculum of each course. This in turn is based on directives issued for each under-graduate programme by professional corporations. In addition to being part of the calculations of CPC and IGP, its results are published online through a classification index that are again ranked from one to five.

In summary, course evaluations and student performance evaluations are both published online separately, and used for decisions on license renewal. There are four main instruments of HE quality assessment in Brazil, all of which are based on a five-point scale: the CPC (preliminary course concept) concerning under-graduate courses; the IGC (general courses index) used to classify institutions as a whole; the ENADE (National evaluation of student's performances) which is part of the former two indicators; and, the IQI, resulting from in loco institutional evaluations required when institutions get less than three in the course indexes. This system displays, as a result, a risk-based approach, according to which worst performers are more thoroughly scrutinised. Apart from the results of in loco evaluations, all indexes are published online and can inform student choice and be used for marketing purposes. 
As can be inferred from the description above, both the licensing and the transparency based regulatory strategies rely on numerical performance indicators. They are distinct, however, in their objectives or in the way in which the numbers are used (Hood, 2012). While the first applies a 'target' rationale, according to which institutions have to achieve a minimum standard to be allowed new enrolments, the second deploys a 'ranking' strategy, which regulates information to the 'consumers' stimulating competitive behaviour via public 'naming and shaming' and comparison.

\section{New Modalities of Control and the Brazilian HE 'Regulatory State'}

This analysis has identified two main modalities of control in the latest HE policies in Brazil and both having strong links to the increase in for-profit institutions. First, the design of standardised, centralised criteria of assessment for licensing - a highly hierarchical mode of regulation based on oversight as a modality of control. This departs from self-reflection and learning through self-evaluation and is associated with a regulatory framework that intends to prevents rent-seeking behaviour from private actors. The second modality is a reliance on market or competition-based control. This tendency is manifested through a focus on student satisfaction and opinions in the composition of quality assurance criteria, and second on the online publication of an institutions' evaluations. Although hierarchically mediated by the government, this second regulatory mode incorporates a logic of competition between institutions (which have their evaluations publicly exposed) and competition for students satisfaction. Associated with these two regulatory logics or modalities of control, unintended elements of randomness also become part of the picture. First, in loco auditors might not have specific qualifications in the areas they are evaluating and discretion in the interpretation of evaluation criteria is perceived to be high (OECD 2018: 24). Similarly, ENADE, the student examination, is not perceived as a reliable indicator of student learning and educational quality. The variable degrees of difficulty between years and courses creates barriers to comparability and reliable assessments (OECD 2018: 29). Finally, elements of mutuality are also identified, but they remain high only in post-graduate evaluation. CAPES

uses a system of peer-reviews with a committee formed by academics that discuss an internally agreed set of criteria and have many opportunities of socialisation and debate 
throughout the evaluation process. This is, however, limited to stricto sensus post-graduation courses, which represents a very small percentage of HE students (the total number of postgraduate students in 2017 was only about four percent of the total of new enrolments in under-graduate courses) (Capes, Open data, 2017/2018). Table one below summarises this analysis on the main modalities of control of the Brazilian case and their respective importance.

[Table 1 about here]

Brazilian regulatory governance in $\mathrm{HE}$ is aligned with many international trends associated with the 'regulatory state', but it also displays specificities that have not been identified elsewhere. A comparative analysis of the Brazilian system reveals that, among the commonalities, Brazil is clearly aligned with the global expansion of regulatory oversight through the recent creation of quality assurance instruments and agencies (Jordana 2018). Additionally, the rapid expansion of $\mathrm{HE}$ institutions at a rate that far exceeds population increase, has generated a process of 'massification' with less overall competition for student places (Schuetze and Slowey 2002). The expansion of quality assurance policies and instruments, on the other hand, has promoted a related increase in 'positional competition' or institutional rivalry to gain the top places in rankings and evaluations. This is a common trend identified by the literature in many other countries such as Japan, France, Germany, Netherlands, Australia and UK (Hood and Scott, 2004: 82).

Unlike more developed countries such as the US and in Europe, the hierarchical licensing system in Brazil presents strong elements of command and control, and institutions may even be prevented from operation by the government. This hierarchical orientation breaks with previous trends of self-assessment and the independence of HE institutions and results from the sheer expansion of for-profit participants in the sector. The policy choice of expansion, privatisation and massification has resulted in a transformation of HE regulatory governance. A 'consumer focused' approach of student satisfaction has been accompanied by the abandonment of a previous emphasis on self-assessment and mutuality. What is specific about the Brazilian case is the low reliance on relatively simple and affordable mechanisms of self-assessment and mutual adjustments. Horizontal processes of networking through epistemic communities (such as the European Bologna process), or other collective and 
voluntary arrangements of quality assurance and improvement are not particularly evident in the Brazilian case.

These findings tend to resonate with previous studies on the nature of the Brazilian 'regulatory state', and support the hypothesis that regulatory governance mechanisms in Brazilian HE display a highly hierarchical orientation. Brazil has been regarded as a 'traditionally interventionist State', which despite formally adopting most of the elements of the international regulatory agenda, such as formally independent regulatory agencies and arms' length regulatory mechanisms, still tends to implement them to foster a 'developmental' or positive approach to policy making. (Cunha and Rodrigo, 2012) Institutional shortcomings such as limited levels of regulatory autonomy, blurred competencies between institutions, lack of institutional leadership and commitment towards the 'regulatory state' model, are still perceived in the literature as impediments to the manifestation of the Brazilian 'Regulatory State' (Peci and Sobral, 2011). The general characteristics of Brazilian 'institutional constellation' appear to have directly affected the Brazilian capacity to move away from government, towards a more decentred type of regulation in $\mathrm{HE}$.

\section{Conclusion}

This article described how the Brazilian system of HE regulatory governance changed in the past two decades, contrasted it with broader theoretical expectations and international trends, and pointed to some of the reasons why specific regulatory choices have been adopted in the Brazilian context. Similar to other parts of the world, this analysis points to the emergence of quality assurance tools as fundamental elements of regulatory governance in this sector, breaking with a tradition of direct state funding and control of the sector. As an exception to other places however, Brazil presents a 'risk-based' regulatory approach, according to which the worst performers are hierarchically controlled through in loco visits, while lower risk (or higher quality) institutions are left to be exclusively controlled by competition-based mechanisms. This hybrid oversight-competition approach, is justified by the hierarchical trends of the 'Brazilian Regulatory State' associated with the limits of Brazilian state capacity to rely exclusively on oversight. Another particularity of the Brazilian case is the relatively low reliance on horizontal networks and epistemic community cooperation seen as an element of quality control and improvement. 
Although an analysis of the consequences of these changes is beyond the scope of this paper, it is possible to foresee unintended consequences of these regulatory choices. Policies that equate HE quality to attracting and satisfying the highest possible number of students may push students and academics to completely disengage with the production of knowledge, condemning Brazilian academia to a future dependence of critical thinkers from elsewhere. The will impact of this system on academic quality and research productivity, is one of the most pressing areas to be addressed by policy makers and academics. As to the economic and political power of large private educational conglomerates affecting regulatory decision making this is another issue that needs to be considered. Tracing the channels and directions of influence (or regulatory 'capture') is an open and important avenue for future research on the area. Similarly, the pedagogical consequences of concentrating so many students in very few institutions, raises fundamental questions regarding teaching standardisation and massification.

In conclusion, recent policy changes to regulatory governance of $\mathrm{HE}$ in Brazil, while similar to many other contexts in its explosion of quality assurance mechanisms, retains considerable 'centralised' or 'hierarchical' control over their implementation. Further research on the particularities and risks associated with this system will be important, not only to provide more critical educational policies, but also to enhance academics' awareness and clarity on the trajectories of their own fate.

\section{References}

Ayres, I. Braithwaite, J. (1992) Responsive Regulation. Oxford University Press: Oxford.

Almeida de Carvalho, C. H. (2006) 'O prouni no governo Lula e o jogo político em torno do acesso ao ensino superior'. Educação and sociedade 27(96): 979-1000.

Black, J. (2001) 'Decentring Regulation: Understanding the Role of Regulation and Self Regulation in a "Post-Regulatory" World'. Current Legal Problems 54: 103-147

Billing, D. (2004) 'International Comparisons and Trends in External Quality Assurance of HE: Commonality or Diversity?' Higher Education, 47(1): 113-137.

Brennan, J. and Shah, T. (2000) Managing Quality in HE: An International Perspective on Institutional Assessment and Change. Open University Press: Bristol. 
Câmara dos Deputados (Deputy's Chamber). Legislação Informatizada - DECRETO $N^{o}$ 7.247, DE 19 DE ABRIL DE 1879 - Publicação Original [WWW document]. URL https://www2.camara.leg.br/legin/fed/decret/1824-1899/decreto-7247-19-abril-1879547933-publicacaooriginal-62862-pe.html [accessed 13 May 2020]

Capes - Dados Abertos. Discentes da pós-graduação stricto sensu do Brasil. [WWW document]. URL https://dadosabertos.capes.gov.br/organization/diretoria-de-avaliacao. [accessed 14 January 2020].

Capes - Dados Abertos. Programas da pós-graduação Stricto Sensu no Brasil. [WWW document]. URL https://dadosabertos.capes.gov.br/organization/diretoria-de-avaliacao [accessed 14 January 2020].

CNE - Conselho Nacional de Educação (National Educational Council). Resoluções do CNE. $\begin{array}{llllll}\text { Resolução } \quad \mathrm{n}^{\circ} & 2, & 23 / 03 / 2017 & \text { [WWW document]. URL }\end{array}$ http://portal.mec.gov.br/conselho-nacional-de-educacao/atos-normativos--sumulaspareceres-e-resolucoes?id=12816 [accessed 13 May 2020].

CNE - Conselho Nacional de Educação (National Educational Council). Resoluções do CNE. CNE/CES decisão $n^{o}$ 218/2007, aprovada em 18/10/2007_[WWW document]. URL http://portal.mec.gov.br/cne/arquivos/pdf/2007/pces218_07.pdf [accessed 13 May $\underline{20201}$

Cunha, B. Q. and Rodrigo D. (2012) Regulatory Governance in Brazil: inconsistent coordination, institutional fragmentation and halfway reforms. Paper presented at the 4th Biennial ECPR Standing Group for Regulatory Governance Conference, University of Exeter, UK (27 to 29 June).

Davies, N. (2016) 'A política educacional nos governos do PT: continuidades ou descontinuidades em relação aos do PSDB?' Revista HISTEDBR On-line, 67: 39-52.

Dubash, N. K. and Morgan, B. (2012) Understanding the Rise of the Regulatory State of the South. Regulation and Governance. 6: 261-281.

Gunningham N. and Grabosky P. (1998) Smart Regulation: Designing Environmental Policy. Clarendon Press: Oxford. 
Jarvis, D.S.L. (2014) 'Regulating HE: Quality Assurance and Neoliberal Managerialism in HE-A Critical Introduction', Policy and Society, 33(3): 155-166.'

Jordana, J. (2011) The Institutional Development of the Latin American Regulatory State in D. Levi-Faur (ed.) Handbook on Regulation. Edward Elgar Press, Manchester, 156170.

Jordana, J. (2018) Uniregov Project: A Conceptual Framework. Institut Barcelona d'Estudis Internacionals (IBEI) [WWW document] URL https://www.globalreg.info/uploads/1/2/2/4/122419256/conceptual_framework.pdf [accessed 14 January 2020].

Jordana, J. and Sancho, D. (2004) 'Regulatory Designs, Institutional Constellations and the Study of Regulatory State' in J. Jordana and D. Levi-Faur (eds.) The Politics of Regulation: Institutions and Regulatory Reforms for the Age of Governance. Edward Elgar Publishing: Cheltenham, UK.

Hood, C. (2012) 'Public Management by Numbers as a Performance-Enhancing Drug: Two Hypotheses'. Public Administration Review, 72(S1), S85-S92.

Hood, C. and Scott, C. (2004) 'HE and University Research: Harnessing Competition and Mutuality to Oversight?' in Hood, C., James, B., Peters, G. and Scott, C. (eds.) Controlling Modern Government. Edward Elgar: Cheltenham UK.

INEP - Instituto Nacional de Estudos e Pesquisas Educacionais Anisio Teixeira (Anísio Teixeira National Institute of Educational Studies and Research) $(1999,2018)$ Census da educação superior sinopses e microdados. [WWW document]. URL http://www.inep.gov.br/ [accessed 22 July 2018].

Kelemen, R.D. and Vogel, D. (2010) 'Trading Places: The Role Of The United States And The European Union in International Environmental Politics'. Comparative Political Studies 43(4): 427-56.

King, R. P. (2007) 'Governance And Accountability in The HE Regulatory State'. Higher Education, 53(4), 411-430.

Majone, G. (1997) 'From the Positive to the Regulatory State. Causes and Consequences of Changes in the Mode of Governance'. Journal of Public Policy, 17(2), 139-67. 
Ministério da Educação (ME, Ministry of Education (2018) Normative Acts. [WWW document]. URL http://portal.mec.gov.br/conselho-nacional-de-educacao/atosnormativos--sumulas-pareceres-e-resolucoes [accessed 22 July 2019]

Ministério da Educação (ME, Ministry of Education) (2018) Credenciamento, recredenciamento. [WWW document]. URL http://portal.mec.gov.br/index.php?option=com_content\&view=article\&id=12809 [accessed 22 July 2019]

Ministério das Relações Exteriores (MRE, Ministry of Foreign Affair) (2018) Denominações das instituições de ensino superior. [WWW document]. URL http://www.dce.mre.gov.br/nomenclatura_cursos.html_[accessed 22 July 2018].

Neave, G. (1998) 'The Evaluative State Reconsidered', European Journal of Education 33(3), 265-268.

Nunes, E. D. O., Fernandes, I. and Albrecht, J. V. (2014) 'Regulação e ensino superior no Brasil'. Observatório Universitário, 112: 1-59.

OECD (2018) Repensando a garantia de qualidade para o ensino superior no brasil.

Revisões das políticas nacionais para educação. [WWW document]. URL http://download.inep.gov.br/acoes_internacionais/ocde/Repensando_a_Garantia_de_Qu alidade_para_o_Ensino_Superior_no_Brasil_PT.pdf [accessed 14 January 2020]

Oliveira, R. P. De. (2009) 'A transformação da educação em mercadoria no brasil' Educação e Sociedade, 30(108): 739-760.

Schuetze, H.G., Slowey, M. (2002) 'Participation And Exclusion: A Comparative Analysis Of Non Traditional Students And Lifelong Learners In HE'. Higher Education 44: 309327

Peci A. and Sobral F. (2011) 'Regulatory Impact Assessment: How Political and Organizational Forces Influence Its Diffusion in a Developing Country'. Regulation \& Governance 5: 204-220.

Pierson, P. (2000) 'Increasing Returns, Path Dependence, and the Study of Politics'. American Political Science Review, 94(2): 251-267. 
Prado M (2008) 'The Challenges and Risks of Creating Independent Regulatory Agencies: A Cautionary Tale from Brazil'. Vanderbilt Journal of Transnational Law, 41: 435-503.

Radaelli, C (2004) 'The Puzzle of Regulatory Competition' Journal of Public Policy 24(1): $1-23$

Scott, C. (2004) 'Regulation in the Age of Governance: The Rise of the Post Regulatory State' in J. Jordana and D. Levi-Faur (eds.) The Politics of Regulation: Institutions and Regulatory Reforms for the Age of Governance. Edward Elgar: Cheltenham UK, 145174.

Unesco - The United Nations Educational, Scientific and Cultural Organization (2020)

Education data - enrolment in tertiary education, all programmes, both sexes. [WWW document]. URL http://data.uis.unesco.org/\# [accessed 13 May 2020]

Vogel, D. (1986) National Styles of Regulation. Environmental Policy in Great Britain and the United States. Cornell University Press: Ithaca and London.

Vogel, S (1997) 'International Games with National Rules: How regulation shapes competition in "global markets"'. Journal of Public Policy, 17(2): 169-193.

Verhine, R. and Dantas, L. V. (2017) 'Educação superior com fins lucrativos e responsabilidade social'. ABMES [WWW document]. URL https://responsabilidadesocial.abmes.org.br/index.php/noticias/artigos/254-educacaosuperior-com-fins-lucrativos-e-responsabilidade-social [accessed 22 July 2019].

\section{Newspapers}

Salomão, K 2018, As 20 empresas que tiveram os maiores lucros de 2017, Exame, 3 April, [WWW document] URL_https://exame.abril.com.br/negocios/as-20-empresas-quetiveram-os-maiores-lucros-de-2017/ [accessed 22 July 2019]. 
Toledo, L F 2016, Apenas 8 grupos privados concentram 27,8\% das matriculas do ensino superior, O Estado de São Paulo, 8 June [WWW document] URL http://educacao.estadao.com.br/noticias/geral,apenas-8-grupos-privados-concentram27-8-das-matriculas-do-ensino-superior,10000055857 [accessed 22 July 2019].

Table 1. Modalities of Control in the Brazilian Case

Control form Importance in the Justification Brazilian case

\begin{tabular}{lll}
\hline Oversight & High & $\begin{array}{l}\text { Initial authorisation process followed by periodic licensing } \\
- \text { worst achievers are forbidden to operate. }\end{array}$ \\
Mutuality & Low & Restricted to post-graduation evaluations.
\end{tabular}

Competition High Positional competition through the online publication of quality assessment results.

Competition for students' satisfaction thought the incorporation of students' satisfaction in quality assessment criteria.

Contrived Medium

Mostly unintended. Issues of measurement validity and randomness reliability. Lack of consistency between different in loco inspectors/discretion in the interpretation of criteria. Variable degrees of difficulty of the national student evaluation (ENADE) between courses and years. 
Source: Originally produced by the author of this article 